\title{
Evaluation of Organizational Commitment Models and their components in Asian Cities
}

\author{
Anthony Wong \\ Caritas Institute of Higher Education \\ Hong Kong SAR, China \\ Email: awong@cihe.edu.hk \\ Canon Tong \\ University of Canberra \\ Australia. \\ Email: canon.tong@gmail.com
}

Doi:10.5296/ijhrs.v4i2.5601

URL: http://dx.doi.org/10.5296/ijhrs.v4i2.5601

\begin{abstract}
Most studies in organizational commitment that conducted in Asian cities employed the three-component model of Meyer and Allen (1991). The five-component organizational commitment model of Wang (2004) had provided a better explanation of organization commitment behaviour in her research. In order to evaluate the appropriateness of Wang's model, this research used her five-component model in studying the organizational commitment in Hong Kong. This research also provided an evaluation of its results with other relevant research in Asian cities in order to compare the organizational commitment behaviour in this area. Data was collected from 310 Information and Communication Technology (ICT) professionals in Hong Kong. Results indicate that Wang's model is more appropriate than other western models in describing employees' commitment in Hong Kong. By comparing the data collected in this research and recent findings from other researchers in Asian cities, the evaluation of these results indicates that the level of organizational commitment in Hong Kong is higher than those in other Asian cities.
\end{abstract}

Keywords: Organizational Commitment, Affective, Active, Passive, Normative, Value, Asian

\section{Introduction}

The purpose of this research is to study the organizational commitment in Hong Kong context and evaluate the extent of different components of organizational commitment with other relevant literatures that conducted in Asian cities. IT professionals will have a higher commitment to organizations and remain working in their organizations if their jobs are 
stimulating and challenging in nature and there are opportunities for advancement in the ICT industry (Bashir \& Ramay, 2008). By considering these issues, this research aimed to study the organizational commitment behaviour in the ICT industry in Hong Kong. Chen \& Francesco (2003) and Cheng \& Stockdale (2003) applied Meyer \& Allen's (1991) three-component organizational commitment model to their studies in China, and Wong, Ngo \& Wong (2002) studied affective commitment in a Chinese context. Both of the studies used Western models to study organizational commitment in a Chinese context. One of the aims of this research was to apply the five-component organizational commitment model by Wang (2004) to the Hong Kong context. Analysis was conducted to compare Wang's model and also the results of this research with other literatures conducted in Asian cities.

\section{Literature Review}

Studying employee behaviour of organizational commitment becomes a challenging human resources management issue for senior managers to enhance competitive advantage of an organization. The organizational commitment models have been formulated 40 years ago. They are becoming more and more important in the modern business and management environments. Most studies show that organizational commitment affects employees' attitudes and behavior towards an organization, such as turnover intention, job satisfaction, job involvement, work experiences, and organizational citizenship behavior (Mathieu \& Zajac, 1990; Porter, Steers, Mowday \& Boulian, 1974). Those studies also show that organizational commitment significantly improves an organization's competitive advantages by enhancing their performance.

\subsection{Development of Organizational Commitment}

Becker (1960) identified a concept of commitment that is widely used by researchers studying organizational commitment. Becker's (1960) concept is that employees will continue to work in the same organization as long as there is the possibility of an exchange of value with the organization that would be lost if they resigned. Employees have a higher commitment to continuously working in their organization if they know that the value of their provident or retirement fund will increase in relation to the number of years that they work in the organization. In some cases, the longer the employees stay in their organization the more special benefits they can enjoy.

Becker's (1960) concept is known as the calculative approach to commitment. As an alternative to that approach, a study by Porter et al. (1974) focused on the attitudinal approach to organizational commitment and produced a model that considered three factors in formulating an attitude towards a positive commitment to an organization; a strong belief in and acceptance of the organization's goals and values, a willingness to exert considerable effort on behalf of the organization, and a definite desire to maintain organizational membership. The model focuses on the identification of an individual employee's role and involvement in a particular organization and measures only the affective element of organizational commitment. Employees with higher identification and involvement in an organization will have higher job satisfaction and consequently higher commitment. Such employees are more likely to accept and recognize the values and goals of the organization, 
and are also more likely to make an effort to maintain the values and achieve the goals.

Another approach to studying organizational commitment was initiated by O'Reilly \& Chatman (1986) who explored the employees' psychological attachment to the organization by considering the attitude changes of compliance, identification, and internalization that Kelman (1958) had identified. Compliance is the commitment to organization by gaining specific rewards; identification is an individual's acceptance of change by identifying his/her roles, values and goals and the relationship with the organization; and internalization is whether an individual's and an organization's goals and values are aligned. The resulting model not only considers emotional behavior but also the instrumental involvement and altruistic attitude of employees in helping their organization to achieve critical goals.

Lin (2007) argued that employees' commitment to their organization is also related to their behavior toward other members of the organization, in terms of trust and group membership, and that employees will more likely have feelings of commitment to the organization if they have a good relationship with their peers. Organizations can motivate positive behavior and foster better relationships between employees by encouraging them to share the organization's goals and values and to realize that it will benefit them by doing so.

\subsection{Meyer \& Allen's (1991) Model}

Meyer \& Allen (1991) were the first to argue that attitudinal and behavioral issues are correlated and need to be considered together in order to arrive at a more accurate measurement of employee commitment. Meyer \& Allen (1991) described attitudinal commitment as the process in which employees consider their relationship with the organization in terms of whether their own values and goals are congruent with those of the organization. Behavioral commitment on the other hand was described as the processes by which individual employees engaged into a particular organization. They also suggested that the psychological attachment that employees often have to an organization is not limited to values and goals but also reflects a desire, a need and/or an obligation to maintain membership of the organization.

The organizational commitment model developed by Meyer \& Allen (1991) effectively integrated the approaches by Becker (1960), Porter et al. (1974) and Mowday, Steers \& Porter (1979) by including three components; affective commitment, continuance commitment, and normative commitment. Affective commitment is a psychological aspect of an employee's willingness to commit to an organization, continuance commitment is about the cost of leaving an organization and normative commitment is concerned with the obligation of an employee to the organization. These three components comprise employees' emotional and psychological attachment to and involvement in an organization (Meyer \& Allen, 1997), as well as the attitude of individual employees when considering their relationship with the organization (Brooks, 2002).

\subsection{Assessment of Western Models}

Since its development, Meyer \& Allen's (1991) organizational commitment model has been widely applied and studied by other Western researchers. However, these researchers have 
defined different components of organizational commitment and have sometimes attributed similar meanings to them. For example, organizational identification and organizational attachment share a similar meaning but continuance commitment has different interpretations by Meyer \& Allen (1991) and Mayer \& Schoorman (1992).

Jaros (1997) studied the effects of two scales of continuance commitment identified by McGee \& Ford (1987). One scale, termed CC-loalt, related to the lack of employment alternatives in other companies, whilst the other scale, termed CC-hisac, related to the loss of benefits. These two sub-scales of continuance commitment were classified as active and passive considerations. CC-hisac was an active consideration because an employee could determine whether to leave or stay in an organization based on a calculation of personal benefits, whilst CC-loalt was a passive consideration because employees could not control alternative employment opportunities. Jaros (1997) found that CC-hisac was negatively correlated with turnover but that CC-loalt was not.

Confirmatory factor analysis was conducted by Hackett, Bycio \& Hausdorf (1994) to compare the difference between Meyer \& Allen's (1991) three-component model and a four-component model produced by including the two sub-scales of continuance commitment described above. The results supported the three-factor model by Meyer \& Allen (1991) by showing that the two sub-scales were correlated and therefore made no significant difference to the four-component model. More recently, Tayyab (2007) and Labatmediene, Endriulaitiene \& Gustainiene (2007) conducted similar confirmatory tests, with both studies showing that the four-component model did not improve Meyer \& Allen's (1991) three-component model.

Although most of the applications and testing of organizational commitment models have been in Western countries, Chen \& Francesco (2003) and Cheng \& Stockdale (2003) studied the model in a Chinese context. Chen \& Francesco (2003) found from their study of the relationship between organizational commitment and performance in 253 pairs of supervisor-subordinate of a large pharmaceutical manufacturer in South China that the affective component was the most significant component in organizational commitment, just as in a Western context. Significantly, Chen \& Francesco (2003) used two sub-scales of the continuance commitment component in their studies and found that the two scales were correlated and indistinguishable from one another; they concluded that continuance commitment should be a single component.

From the foregoing review of organizational commitment models it is apparent that affective commitment has a more significant effect on organizational commitment than other components and that it is the most commonly studied component; it is also apparent that continuance commitment should be considered as an indivisible component (Mathieu \& Zajac, 1990; Meyer, Allen \& Smith, 1993; Hackett et al., 1994; Jaros, 1997). However, since some models were applied in a Western context and some in a Chinese context, it is not apparent whether they could be validly applied to the study of employee commitment in Hong Kong. This is the research gap that this study fills.

\subsection{Wang's (2004) Model}


Before developing her own model of organizational commitment, Wang (2004) considered models developed by other researchers, such as Takao (1998; cited in Wang, 2004) and Ling, Zhang \& Fang (2001). Figure 1 below shows a four-component model that was developed by Takao (1998) from the ideas of Sekimoto and Hanada (1987; cited in Wang, 2004) whose work had been confirmed as valid in the Asian context.

\begin{tabular}{ll|l}
\hline $\begin{array}{c}\text { Affective } \\
\text { (emotional) }\end{array}$ & $\begin{array}{l}\text { Active } \\
\text { (rational) }\end{array}$ \\
\hline Normative & Continuance \\
& Passive
\end{tabular}

Figure 1 Four-component Model by Takao (1998) [cited in Wang, 2004]

Since Japan and China are in the same geographical region and historically share a common culture, Wang (2004) considered that employees in China might share some of the characteristics of organizational commitment as employees in Japan. She therefore examined a model developed by Ling et al. (2001) from a study of organizational commitment in China. Figure 2 shows the model by Ling et al. (2001).

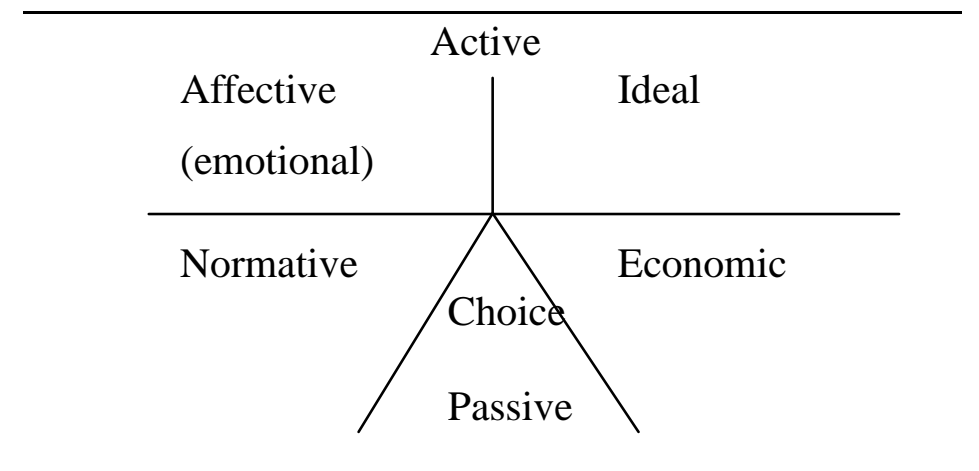

Figure 2 Four-component Model by Ling et al. (2001)

Wang (2004) found that descriptions of economic and choice commitments by Ling et al. (2001) were similar to the personal sacrifices and employment alternative of continuance commitment defined by Western researchers. Wang (2004) then adapted Ling et al.'s (2001) model by considering the active and passive approaches by Takao (1998), and the Western model; she then proposed her own five-component organizational commitment model. The five components are normative, value, affective, active, and passive continuance. The construct of the model is shown in Figure 3 below. 


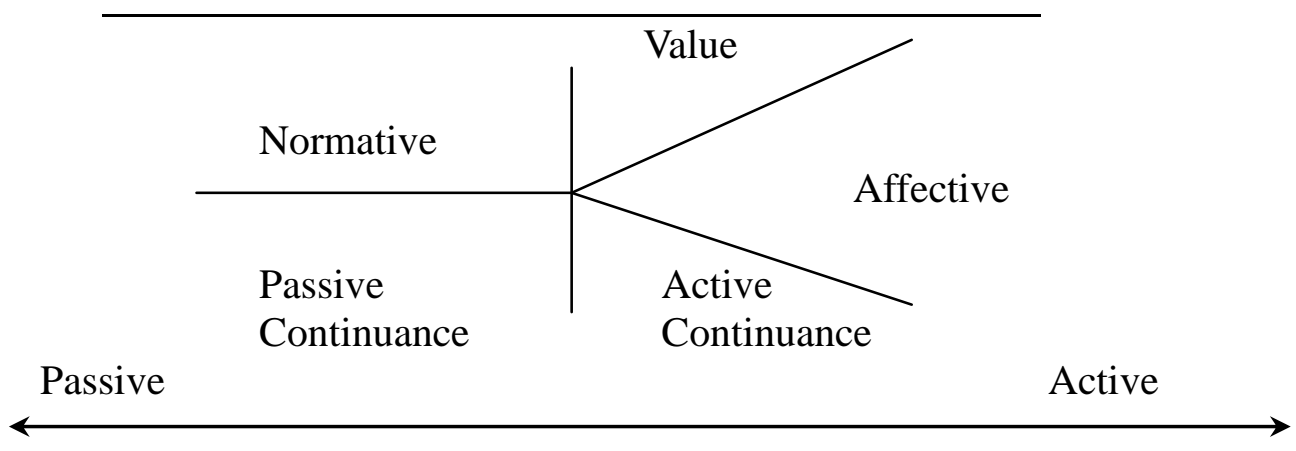

Figure 3 Wang's (2004) Five-component Model

Wang's (2004) model shows affective commitment and normative commitment used to measure emotional attachment and obligation to stay with the organization respectively, to be the same as in the models developed by Ling et al. (2001) and Meyer \& Allen (1991). Wang (2004) integrated ideas from McGee \& Ford (1987) concerning the two scales of continuance commitment, as well as ideas from Takao (1998) concerning passive approaches, but developed her own approach to measuring the active and passive subscales of continuance commitments that Ling et al. (2001) had considered appropriate to cultural considerations in a Chinese context.

Asian countries, especially China, have been classified as having a dominant high collectivistic culture where employees are more loyal to the organization. Employees are less afraid of losing benefits but look for more opportunities in personal development when considering whether or not to stay with the organization (Hofstede, 1993). Value commitment, although not included in Meyer \& Allen's (1991) model, was not a new idea by Wang (2004) as it had been first suggested by Angle \& Perry (1981) and further elaborated by Mayer \& Schoorman (1992). Their ideas of value commitment concerned employees' support of organizational goals and their belief in and acceptance of those goals (Mayer \& Schoorman, 1992). Wang (2004) had a similar interpretation of value commitment in a Chinese environment believing that the harmonious and loyal nature of Chinese people meant that they are more likely to follow and accept organizational goals in order to maintain stable employer-employee relationships. This component is relatively more important when measuring Chinese employees' organizational commitment than Western employees who are more individualistic (Hofstede, 1993).

Wang (2004) conducted a confirmatory factor analysis to test the appropriateness of her model as well as models from other researchers. The results found that her five-component model was best suited to the data collected from her studies of both state-owned and foreign-invested enterprises in China than the models by Meyer \& Allen (1991) and Ling et al. (2001). However, as this contradicts findings from Cheng \& Stockdate (2003) and Chen \& Francesco (2003) that a three-component model is better suited to studying organizational commitment in a Chinese environment, it is meaningful to research this topic further. 


\subsection{Hypotheses Development}

The five components of Wang's (2004) organizational commitment model are used to test the extent of employees' commitment in Hong Kong's ICT industry. Before analyzing data collected from respondents in Hong Kong's ICT industry it was necessary to determine whether it was more appropriate to use Wang's (2004) model or other organizational commitment models such as those developed by Meyer \& Allen (1991), McGee \& Ford (1987), and Ling et al. (2001). The first hypothesis of this research was therefore developed as follows.

Hypothesis 1: Wang's (2004) five-component organizational commitment model is more appropriate for describing the organizational commitment of employees in Hong Kong's ICT industry.

Previous research studied the effects of various demographic variables on organizational commitment. Hackett et al. (1994) found that age and organization tenure are positively related to affective and continuance commitment but not to normative commitment. However, Meyer et al. (1993) found that both affective and normative commitments are higher in older employees and those with longer tenure, but made no difference to continuance commitment. Recent research contradicted this with Bashir \& Ismail Ramay (2008) finding that age and organization tenure have no effect on organizational commitment and Labatmediene et al. (2007) finding that age is positively correlated with continuance commitment but not with other components. Because of the different findings, the second hypothesis considered demographics.

Hypothesis 2: Demographic variables positively influence organizational commitment of employees in Hong Kong's ICT industry.

\section{Research Method}

\subsection{Sample}

Simple random sampling technique was used for this research because it involved a study of companies in Hong Kong's ICT industry. Data was collected from 310 ICT professionals in a random sample size of 500 organizations. All the organizations were either publicly listed on the Hong Kong Trade Development Council's website (www.tdctrade.com) or were members of local ICT associations. The names of all the organizations obtained from these sources were input to a computer program for random selection. The response rate was expected to be at least $30 \%$.

\subsection{Data Collection and Questionnaire Design}

A website-based self-administered anonymous electronic questionnaire was used to collect responses. According to Bryman (2004), not only questionnaires posted to the Internet are more economical and reach a larger number of respondents but respondents also feel more 
comfortable submitting an Internet-based questionnaire rather than having to go to the bother of returning a paper-based questionnaire by post. The five-component model by Wang (2004) in her studies of Chinese employees on organizational commitment was used in this research. The five components are affective commitment, normative commitment, active continuance commitment, passive continuance commitment, and value commitment. Wang's (2004) questions were replicated in the questionnaire used for this research because the five-component organizational commitment model was considered appropriate for studying Chinese employees. The questions used by Wang (2004) for studying organizational commitment of Chinese employees are shown in Appendix 1.

\subsection{Data Analysis}

Data was analyzed by using confirmatory factor analysis and Pearson product moment correlation. Confirmatory factor analysis (CFA) was used to test the appropriateness of different organizational commitment models to the data collected in this research. CFA is a necessary statistical method for confirming a pre-defined model (Labatmediene et al., 2007; Wang, 2004). Pearson product moment correlation is used for testing association of demographics variables and components of organizational commitment.

\section{Results and Analysis}

\subsection{Characteristics of the Sample}

Table 1 provides a summary of the demographic variables, such as age, gender, education, as well as industry information such as experiences in the ICT industry and sizes of organizations. Over $80 \%$ of the respondents have bachelor degree level of education which shows the importance of organizational commitment in their work. On average, there are over $20 \%$ of respondents from each size of companies (10 to 50 employees, 51 to 100 employees, 101 to 200 employees and more than 200 employees). 
Table 1 Descriptive Statistics - Demographic Variables

\begin{tabular}{|c|c|c|c|}
\hline Demographic Variables & Measures & Frequency & $\overline{\text { Percentage }}$ \\
\hline \multirow[t]{2}{*}{ Gender } & Male & 248 & $81.3 \%$ \\
\hline & Female & 57 & $18.7 \%$ \\
\hline \multirow[t]{5}{*}{ Age } & Younger than 25 years & 26 & $8.5 \%$ \\
\hline & 25 to 30 years & 95 & $30.9 \%$ \\
\hline & 31 to 39 years & 119 & $38.4 \%$ \\
\hline & 40 to 49 years & 61 & $19.7 \%$ \\
\hline & More than 49 years & 6 & $1.9 \%$ \\
\hline \multirow[t]{3}{*}{ Marital Status } & Single & 176 & $57.1 \%$ \\
\hline & Married & 130 & $42.2 \%$ \\
\hline & Others & 2 & $0.6 \%$ \\
\hline \multirow[t]{7}{*}{ Education } & Certificate/Diploma & 8 & $2.6 \%$ \\
\hline & Associate Degree/ & & \\
\hline & Higher Diploma/ & & \\
\hline & Professional Diploma & 33 & $10.7 \%$ \\
\hline & Bachelor Degree & 149 & $48.4 \%$ \\
\hline & Master degree or higher & 118 & $38.3 \%$ \\
\hline & Others & 0 & $0.0 \%$ \\
\hline Monthly Salary & Less than 8,000 & 8 & $2.6 \%$ \\
\hline \multirow[t]{5}{*}{ (HK Dollars) } & 8,000 to 15,000 & 50 & $16.2 \%$ \\
\hline & 15,001 to 28,000 & 110 & $35.7 \%$ \\
\hline & 28,001 to 38,000 & 77 & $25.0 \%$ \\
\hline & 38,001 to 50,000 & 46 & $14.9 \%$ \\
\hline & More than 50,000 & 17 & $5.5 \%$ \\
\hline \multirow[t]{4}{*}{ ICT experiences } & 5 years or less & 80 & $26.0 \%$ \\
\hline & 6 to 10 years & 93 & $30.2 \%$ \\
\hline & 10 to 20 years & 111 & $36.0 \%$ \\
\hline & More than 20 years & 24 & $7.8 \%$ \\
\hline Years of employment & 5 years or less & 144 & $46.6 \%$ \\
\hline \multirow[t]{3}{*}{ in current company } & 6 to 10 years & 100 & $32.4 \%$ \\
\hline & 10 to 20 years & 60 & $19.4 \%$ \\
\hline & More than 20 years & 5 & $1.6 \%$ \\
\hline Size of company & Fewer than 10 & 17 & $5.5 \%$ \\
\hline \multirow[t]{4}{*}{ (Number of employees) } & 10 to 50 & 66 & $21.4 \%$ \\
\hline & 51 to 100 & 63 & $20.4 \%$ \\
\hline & 101 to 200 & 71 & $23.0 \%$ \\
\hline & More than 200 & 92 & $29.8 \%$ \\
\hline
\end{tabular}

Table 2 below shows a comparison of ICT experience with the years of experiences in current company. The data in the table shows that most of the respondents have relatively fewer years of employment in the current company than in the industry (46.6\% against $26.0 \%$ for 5 years or less); many respondents have a greater tendency to work for different companies instead of staying with one company. This data provides support for the worthiness of research into organizational commitment in the ICT industry. 
Table 2 Comparison of ICT Experience and Years of Employment in Current Company

\section{ICT Experience $\quad$ Years of Employment in Current Company}

\begin{tabular}{lrr}
\hline 5 years or less & $26.0 \%$ & $46.6 \%$ \\
6 to 10 years & $30.2 \%$ & $32.4 \%$ \\
10 to 20 years & $36.0 \%$ & $19.4 \%$ \\
More than 20 years & $7.8 \%$ & $1.6 \%$
\end{tabular}

\subsection{Descriptive Analysis of Organizational Commitment}

The organizational commitment model by Wang (2004) was used to study employee commitment to their organization in Hong Kong's ICT industry. Wang's (2004) model has five components, which are: affective commitment (AC), active continuance commitment (ACC), passive continuance commitment (PCC), normative commitment (NC), and value commitment (VC). A five-point Likert scale was used to measure these five variables with ' 5 ' meaning strongly agree and ' 1 ' meaning strongly disagree. The results from respondents on these five measures are discussed below.

\subsubsection{Affective Commitment}

Affective commitment in Wang's (2004) model has the same interpretation as in Meyer \& Allen's (1991) model. It concerns employee's emotional willingness to commit to the organization. Nearly $81 \%$ of respondents ( $13.9 \%$ for ' 5 ' and $66.8 \%$ for ' 4 ') agree that they are extremely glad to choose the company to work for. Approximately $72 \%$ of respondents ( $18.8 \%$ for ' 5 ' and $52.8 \%$ for ' 4 ') agree that they talk up to their friends that the company they are working is a great company to work for. Just over $70 \%$ of respondents $(13.2 \%$ for ' 5 ' and $57.1 \%$ or ' 4 ') agree that they are proud to tell others that they are part of the company that they are working for. An average of approximately $4 \%$ of respondents disagrees with the three questions on affective commitment, which indicates that respondents' affective commitment to their companies is at a high level. Figure 4 below shows the percentage response to each of the questions in this construct. 


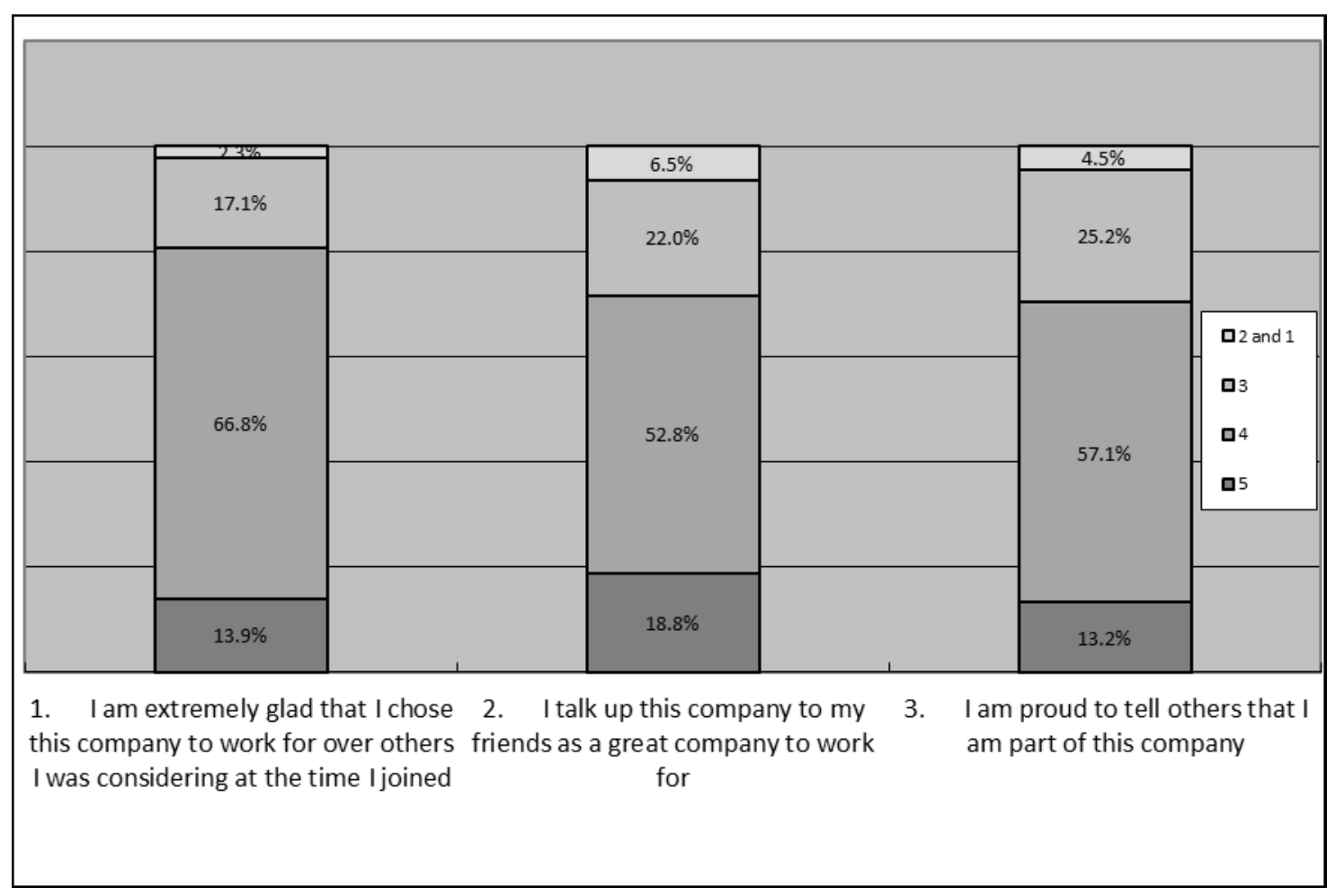

Figure 4 Results of Affective Commitment

\subsubsection{Active Continuance Commitment}

Active continuance commitment in Wang's (2004) model concerns the motivation of employees to stay in organizations that provide opportunities for on-the-job training or promotion opportunities. Approximately $76 \%$ of respondents $(21.8 \%$ for ' 5 ' and $54.4 \%$ for '4') agree that the company provides them with many on-the-job training opportunities. Just over $76 \%$ of respondents $(27.3 \%$ for ' 5 ' and $49.0 \%$ for ' 4 ') agree that the company provides good opportunities for realizing their goals. Almost $74 \%$ of respondents $(21.7 \%$ for ' 5 ' and $52.1 \%$ or ' 4 ') agree that they could make full use of what they have learned in their company. Approximately $77 \%$ of respondents $(21.4 \%$ for ' 5 ' and 55.5 for ' 4 ') agree that the company provides with a challenging job. Just over $54 \%$ of respondents $(15.5 \%$ for ' 5 ' and $38.8 \%$ for '4') agree that the company provides them many opportunities for promotion. An average of approximately $8 \%$ of respondents disagrees with the five questions on active continuance commitment, which suggests that the respondents' active continuance commitment to their companies is generally at a high level. Figure 5 below shows the proportion of agreement, neutral and disagreement for each question in this construct. The fact that, compared to other questions, a relatively lower percentage of respondents agree with the fifth question and a higher percentage disagree with the question suggests that ICT organizations in Hong Kong provide training and challenging jobs for developmental rather than promotional purposes. 


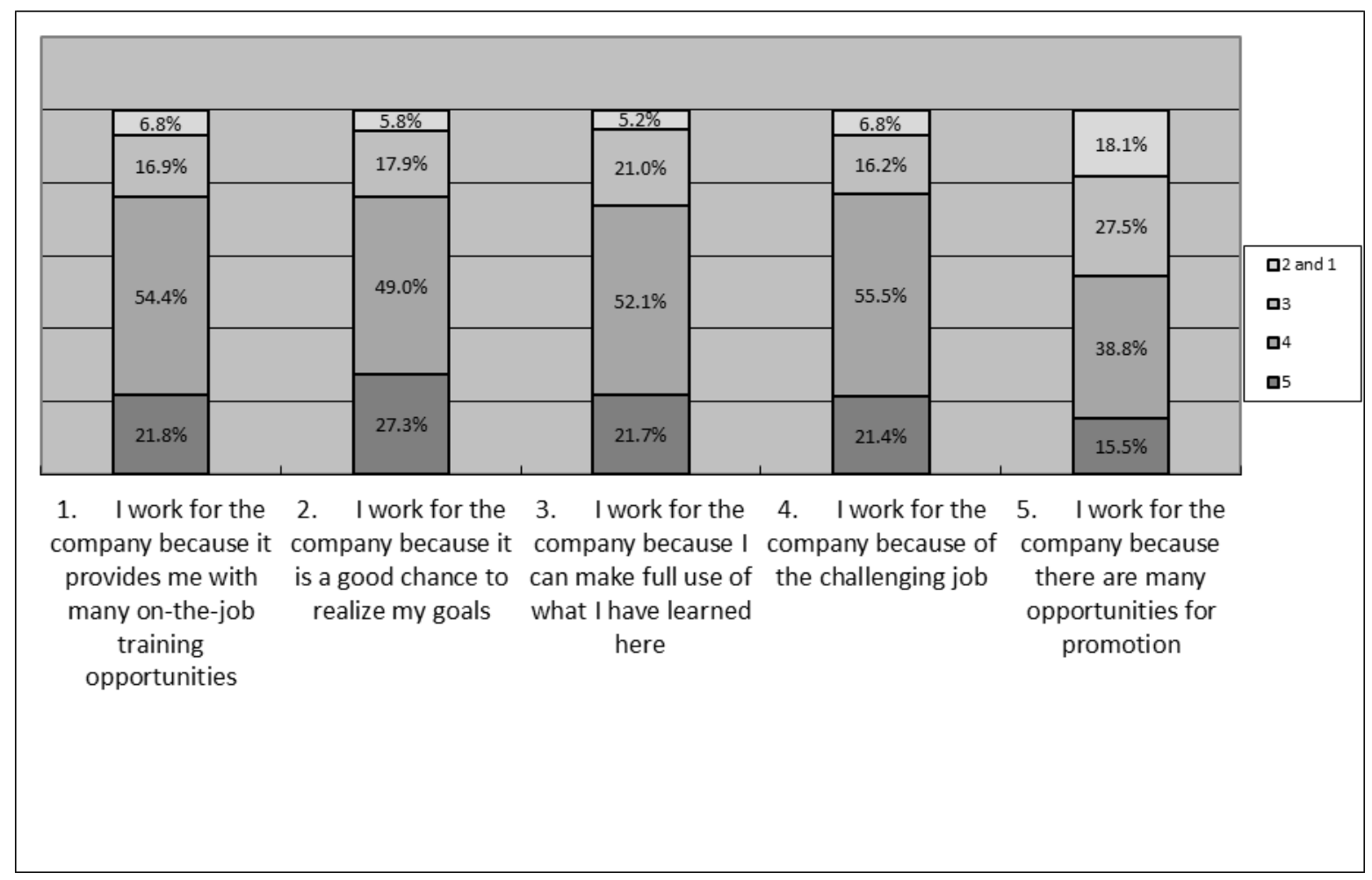

Figure 5 Results of Active Continuance Commitment

\subsubsection{Passive continuance commitment}

Passive continuance commitment is concerned with whether employees choose to stay with their organizations because they could not find a better job in other organizations. Almost $48 \%$ of respondents $(6.8 \%$ for ' 5 ' and $41.9 \%$ for ' 4 ') agree that they cannot find a better company to work for. Nearly $69 \%$ of respondents ( $13.6 \%$ for ' 5 ' and $55.2 \%$ for ' 4 ') agree that they could not quit the job because they need to support their family. Just over $47 \%$ of respondents $(11.0 \%$ for ' 5 ' and $36.1 \%$ or ' 4 ') agree that they work for the company because they do not want to lose fringe benefits. An average of $19.8 \%$ of respondents disagrees with the three passive continuance commitment questions. The results indicate that the respondents' passive continuance commitment to their companies is at a low level compared to previous commitment components. Only the second question has a higher percentage (67\%) of agreement, which might be due to the fact that most of the respondents are male and married and that the question is more important to those respondents who provide the major financial support for their family. Figure 6 below shows the percentage responses for each question in this construct. 


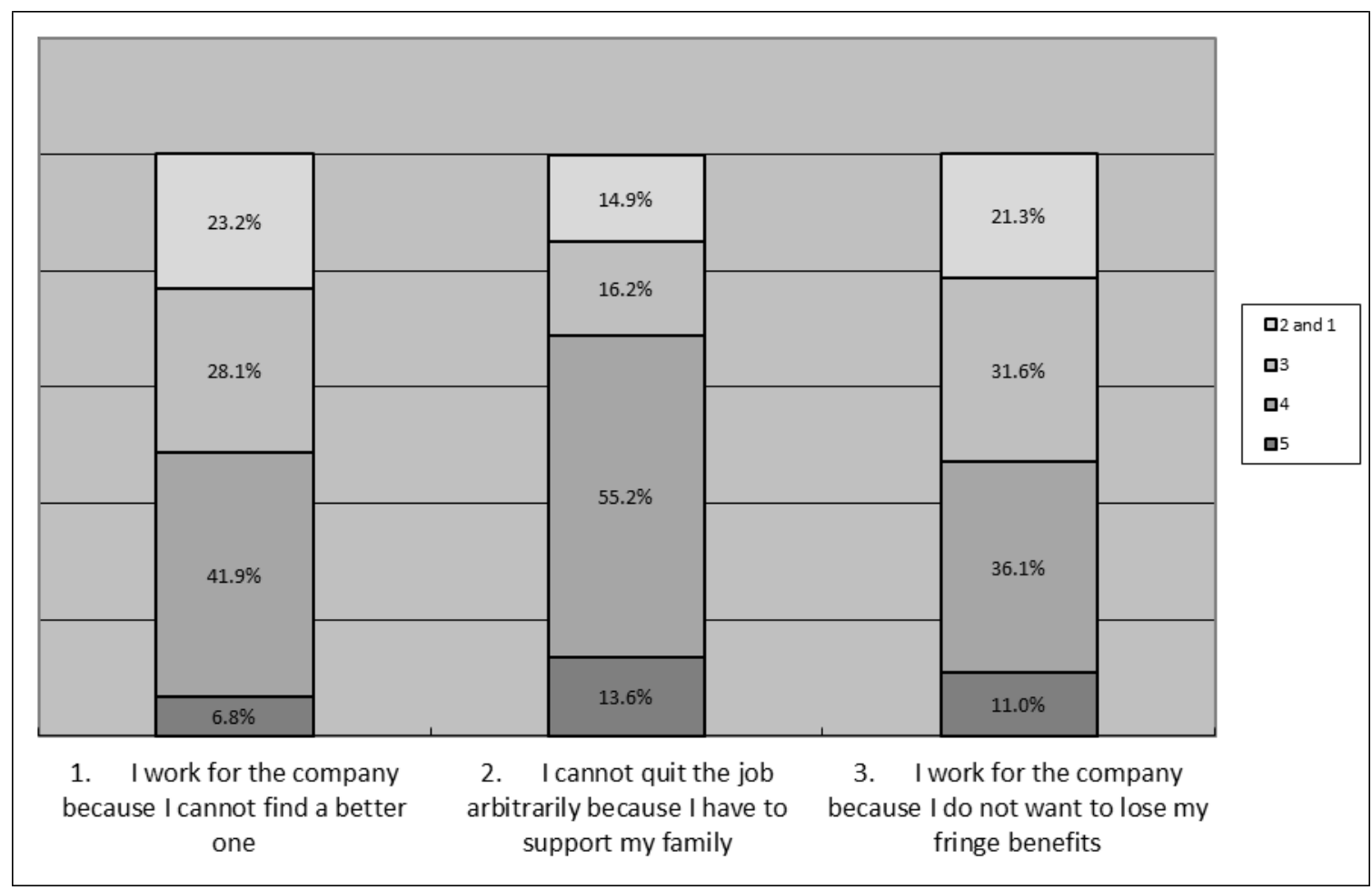

Figure 6 Results of Passive Continuance Commitment

\subsubsection{Normative Commitment}

Normative commitment in Wang's (2004) model adapted the dimension from Meyer \& Allen's (1991) model that tested the obligation of an employee to the organization. Nearly $61 \%$ of respondents ( $3.9 \%$ for ' 5 ' and $56.8 \%$ for ' 4 ') agree that they consider it their obligation to work for the same company for their entire career. Approximately $67 \%$ of respondents ( $14.3 \%$ for ' 5 ' and $52.3 \%$ for ' 4 ') agree that they would like lifetime employment. Just about half of the respondents $(8.1 \%$ for ' 5 ' and $44.5 \%$ or ' 4 ') agree that they would do any job as long as they could work in company. Approximately $10 \%$ of respondents disagree with the three normative commitment questions and about one third of respondents are neutral. The percentages are shown in Figure 7 below. The means of the three questions (NC1 to NC3) are 3.56, 3.69 and 3.44 respectively all of which are lower than other commitment components. The high percentage of neutral responses indicates that even though there is a high level of agreement over this measure, there are still many respondents who are clearly hesitant over whether they should feel obliged to stay with their current employer. 


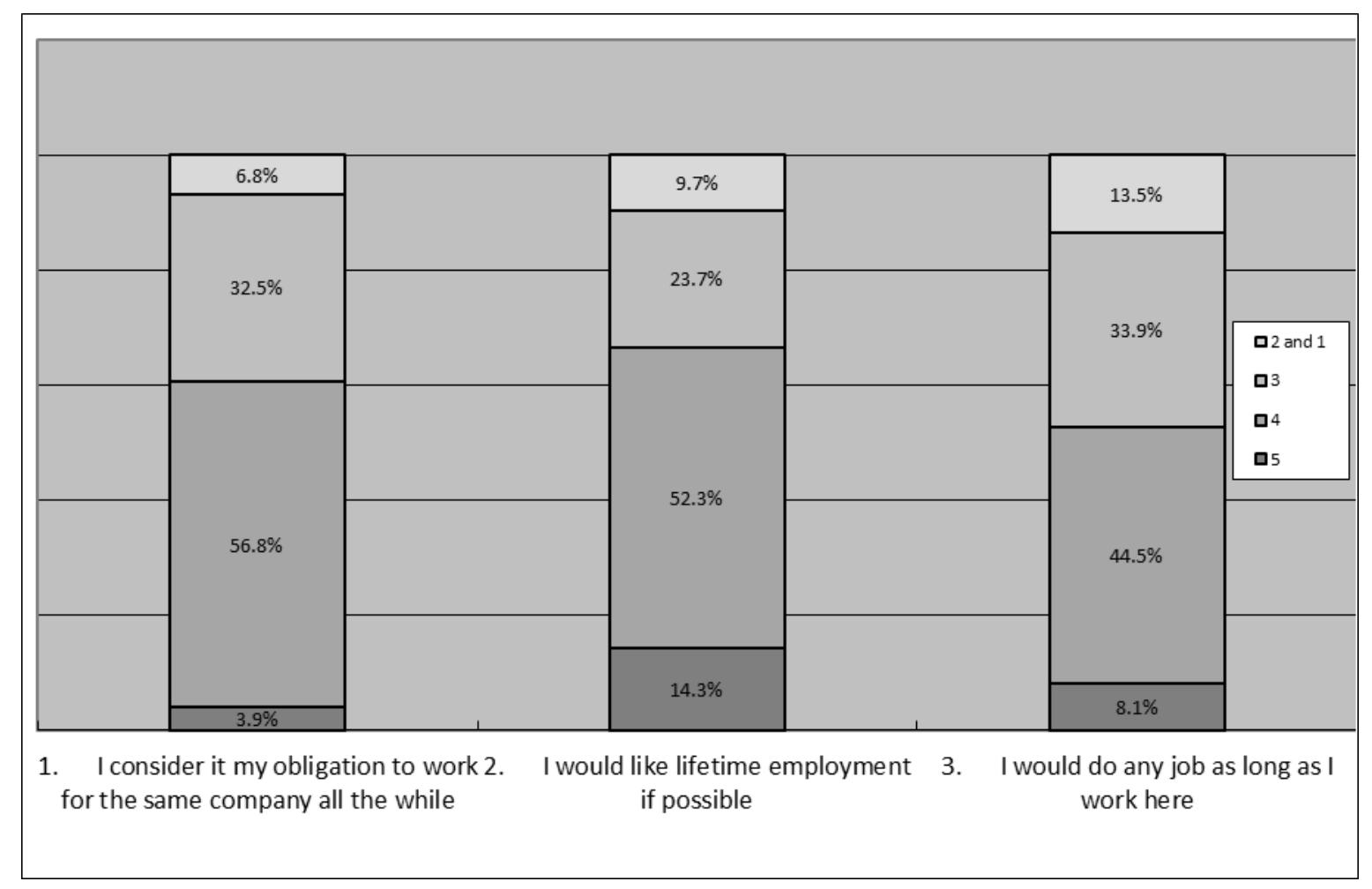

Figure 7 Results of Normative Commitment

\subsubsection{Value Commitment}

Value commitment in Wang's (2004) model is related to an employee's feeling of value with the company and also whether an employee has a willingness to exert considerable effort on behalf of the company. About $85 \%$ of respondents ( $19.1 \%$ for ' 5 ' and $66.0 \%$ for ' 4 ') agree that they are willing to put in a great deal of effort beyond that normally expected in order to help their company succeed. $79 \%$ of respondents $(27.7 \%$ for ' 5 ' and $51.3 \%$ for ' 4 ') agree that they really care about the fate of their company. Approximately $74 \%$ of respondents $(22.4 \%$ for ' 5 ' and $51.3 \%$ or ' 4 ') agree that the company they are working inspires them to do their job to the very best of their abilities. Nearly $79 \%$ of respondents $(18.4 \%$ for ' 5 ' and $60.2 \%$ for '4') agree that one should work with utmost effort for the company. An average of $3 \%$ of respondents disagree with the four questions on value commitment, which indicates that employees in Hong Kong's ICT industry have quite a high level of value commitment to the company they are working for. Figure 8 below shows the percentage response to each question in this construct. 


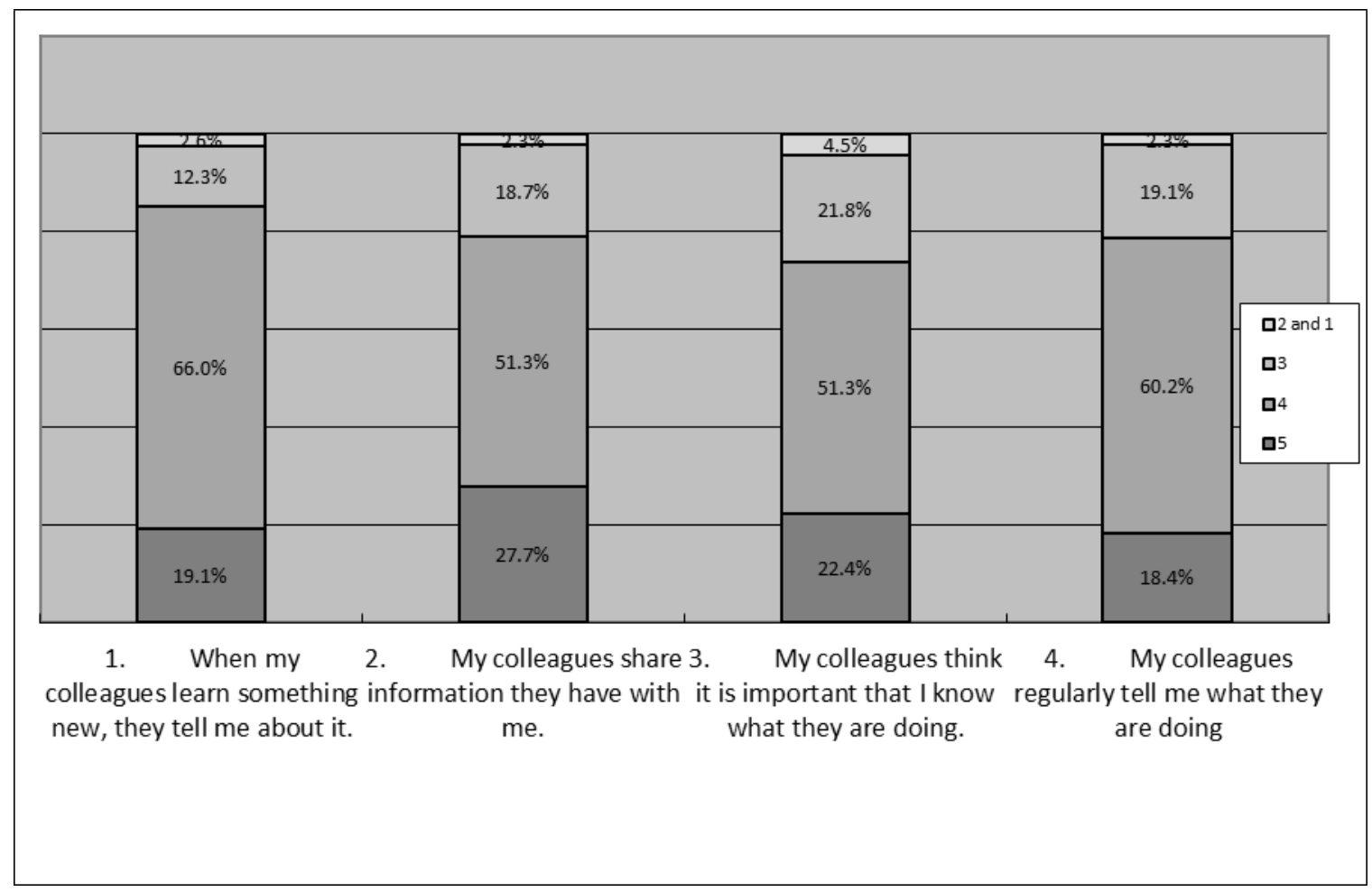

Figure 8 Results of Value Commitment

\subsubsection{Summary}

The Figure 9 shows the mean values of the five components of the organizational commitment model used in this research. Employees working in Hong Kong's ICT industry have strong affective commitment, active continuance commitment and value commitment but relatively weak passive continuance commitment and normative commitment, which mean that they have a high level of emotional attachment to their employer. 


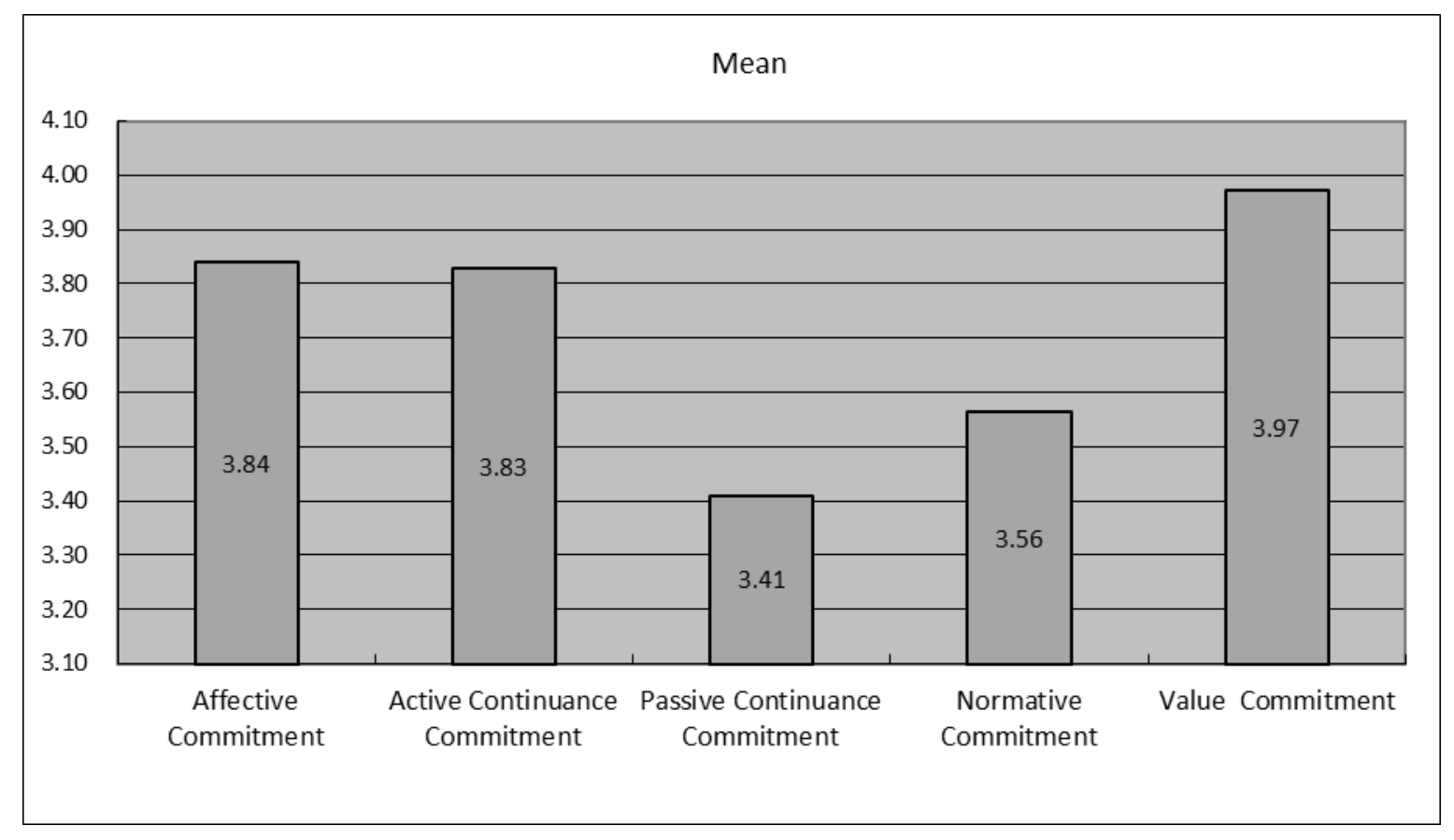

Figure 9 Mean Values of Organizational Commitment

\subsection{Validity and Reliability of Data}

In order to test the validity of the collected data for further statistical analysis, an exploratory factor analysis of the measuring variables using the Principle Components approach with eigenvalue more than 1 and factor loading of each item more than 0.50 was applied. The loadings of all the following items are above 0.5 . In addition, 12 out of 18 items have $(67 \%)$ loading more than 0.7 , which shows that the high level of validity and reliability of the collected data. Exploratory factor analysis treats affective commitment (AC), active continuance commitment (ACC), passive continuance commitment (PCC), normative commitment (NC), and value commitment (VC) are each identified as individual factors.

Table 3 below shows the results of exploratory factor analysis on organizational commitment with the factor loadings of each item within each of the five constructs being greater than 0.50. The five constructs and their items are affective component (items AC1 to AC4), active continuance commitment (items ACC1 to ACC5), passive continuance commitment (items PCC1 to PCC3), normative commitment (items NC1 to NC3), and value commitment (items VC1 to VC4). 
Table 3 Exploratory Factor Analysis on Organizational Commitment

\begin{tabular}{lll}
\hline Construct & Item & Loading \\
\hline Affective Commitment & AC1 & 0.776 \\
& AC2 & 0.842 \\
Active Continuance & AC3 & 0.732 \\
Commitment & ACC1 & 0.564 \\
& ACC3 & 0.551 \\
& ACC4 & 0.569 \\
Passive Continuance & ACC5 & 0.611 \\
Commitment & PCC1 & 0.859 \\
& PCC2 & 0.803 \\
Normative Commitment NC1 & 0.796 \\
& PCC3 & 0.868 \\
Value Commitment & NC3 & 0.705 \\
& VC1 & 0.642 \\
& VC2 & 0.778 \\
& VC3 & 0.805 \\
& VC4 & 0.708 \\
\end{tabular}

Table 4 below shows the KMO measures of sample adequacy test and the Bartlett's Test of Sphericity. The KMO value is more than 0.80 and the value for Bartlett's Test is less than the significant level 0.05 . The results suggest that the components identified are significant and the data collected is appropriate for further statistical analysis.

Table 4 KMO and Bartlett's Test on Organizational Commitment

\begin{tabular}{lll}
\hline \multicolumn{1}{c}{ Tests } & \multicolumn{1}{c}{ Results } \\
\hline Kaiser-Meyer Olkin (KMO) & Measures of Sample Adequacy 0.870 \\
& & \\
Bartlett's Test of Sphericity & Approx. Chi-Square & 2595.683 \\
& df & 153 \\
& Sig. & 0.000 \\
\hline
\end{tabular}

In a reliability test, the item-loading score for each question in a factor should be sufficiently high otherwise the question should be dropped from the factor. It is to ensure that the questions in each factor have high relevance and reliability in formulating the construct. The most common index of reliability is Cronbach's coefficient alpha. Bryman \& Cramer (1997) suggested that the value of Cronbach's alpha value should be at least 0.80 for high reliability.

Table 5 shows the item-loading of each item against the corresponding measured variables along with their Cronbach's coefficient alpha values. For the reliability analysis of the seven constructs that are shown, the item-loading of each item has a high score with a value of at least 0.50 . Although the loading of each item might not be sufficient high, the result shows that the reliability of the items in each construct is satisfactory to formulate that construct. 
The values of Cronbach's coefficient alpha for all scales are more than 0.70 , which shows that the data is reliable for further statistical analysis.

Table 5 Reliability Test for the Measuring Variables

\begin{tabular}{llll}
\hline Construct & Items & Item-Loading & Cronbach's Alpha \\
\hline Affective Commitment & AC1 & 0.585 & \\
& AC2 & 0.794 & \\
Active Continuance & AC3 & 0.654 & 0.815 \\
Commitment & ACC1 & 0.608 & \\
& ACC2 & 0.704 & \\
& ACC3 & 0.642 & \\
Passive Continuance & ACC4 & 0.702 & 0.854 \\
Commitment & PCC1 & 0.693 & \\
\multirow{4}{*}{ Normative Commitment NC1 } & 0.629 & \\
& PCC2 & 0.622 & \\
\multirow{5}{*}{ Value Commitment } & NC2 & 0.536 & \\
& NC3 & 0.524 & 0.713 \\
& VC1 & 0.548 & \\
& VC3 & 0.586 & \\
& VC4 & 0.686 & 0.794 \\
\hline
\end{tabular}

\subsection{Hypotheses Testing}

After a detailed analysis of the data using exploratory factor analysis and reliability analysis, an acceptable level of appropriate validity and reliability of the data was achieved. The data collected then could be used for testing the hypotheses. The two hypotheses were tested by using confirmatory factor analysis and Pearson product moment correlation.

Hypothesis 1: Wang's (2004) five-component organizational commitment model is more appropriate for describing the organizational commitment of employees in Hong Kong's ICT industry.

Confirmatory factor analysis was used to test the above hypothesis. This research has identified four pre-defined factor structures organizational commitment models from the three-component Western organizational commitment model by Meyer \& Allen (1991), four-component organizational commitment model from McGee \& Ford (1987) that with two subscales of continuance commitment (high-sacrifice and low-alternative), the four-component model by Ling, Fang \& Zhang (2001) and Wang's (2004) five-component model. 
Model 1: Affective commitment, Continuance commitment, Normative commitment (A-C-N)

Model 2: Affective commitment, Continuance commitment, Normative commitment, Value commitment (A-C-N-V)

Model 3: Affective commitment, Continuance commitment with high-sacrifice, Continuance commitment with low-alternative, Normative commitment (A-Chs-Cla-N)

Model 4: Affective commitment, Active continuance commitment, Passive continuance commitment, Normative commitment, Value commitment (A-Ca-Cp-N-V)

Table 6 below shows the results of confirmatory factor analysis for the four models

Table 6 Results of Confirmatory Factor Analysis on the Four Models

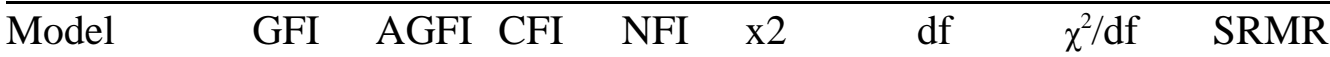

\begin{tabular}{lllllllll}
\hline 1. A-C-N & 0.75 & 0.64 & 0.83 & 0.81 & 650.06 & 74 & 8.785 & 0.14
\end{tabular}

$\begin{array}{lllllllll}\text { 2. A-C-N-V } & 0.80 & 0.72 & 0.88 & 0.86 & 588.80 & 84 & 7.010 & 0.11\end{array}$

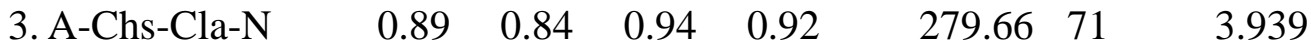

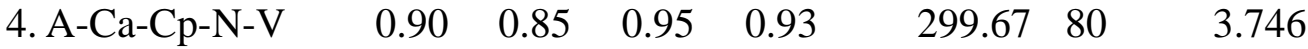

The above table shows that the results of the confirmatory factor analysis of the different organizational commitment models identified by this study are similar to those of Wang's (2004) model. The value of GFI of model 4 (five-component model) is 0.90 whilst the GFI of the other three models are lower than 0.9. This suggests that Wang's (2004) five-component organizational commitment model has a better fit to the data collected in this research. In addition, the indices CFI and NFI of model 4 also are greater than 0.9 and higher than the same indices of model 1 to model 3. Although the index AGFI is below 0.9, it is still the highest one compared to other models and is a further indication that model 4 has the best fit to the data. The ratio $\chi^{2 / d f}$ of model 4 is 3.746. Although it is not below 2 (Mclver \& Carmines, 1981), this value is the lowest among the four models tested. SRMR of model 4 is not below 0.05 , but it is also the lowest value. The confirmatory factor analysis confirms that Wang's (2004) five-component model is more appropriate for describing the organizational commitment of employees in Hong Kong's ICT industry and supports hypothesis 1.

Hypothesis 2: Demographic variables positively influence commitment to organizations of employees in Hong Kong's ICT industry. 
Table 7 shows the correlation matrix between demographics variables and organizational commitment. The Pearson correlation coefficients with two asterisks shown in the correlation matrix in Table 7 show that the variables are significantly correlated at the 0.01 level in the one-tailed correlation test, whilst the variables with coefficients denoted by one asterisk are significantly correlated at the 0.05 level in the one-tailed correlation test. The number of years of work experiences in the ICT industry is positively correlated with passive continuance commitment and normative commitment. This finding shows that with longer years of experience in the ICT industry, employees would have higher obligation to work in the current company. In addition, longer years of experiences imply the possibility of a higher salary and position, so passive continuance commitment is higher. The number of years working in the current company is positively correlated to active and passive continuance commitment, and normative commitment. It is not surprising that employees with longer years of working in the same company have better fringe benefits and also a greater commitment to the organization. The positive effect on active continuance commitment might be because a company would provide more training and promotion opportunities for employees who have been working for the company for a long time.

The age of employees has a positive effect on passive continuance and normative commitment. This might be explained by more mature employees having more years of ICT experiences and therefore high levels of benefits either in a provident fund or the mandatory provident fund as well as a high sense of moral duty to stay with their company. Marital status has a negative effect on active continuance commitment and value commitment, and a positive effect on passive continuance commitment. It is understandable that married employees would look for stable working conditions with good fringe benefits and would not take the risk of quitting a job for purely financial reasons. Married employees might not care too much about training and promotion opportunities or the sharing of values with the organization because stability is likely to be their most critical consideration.

Education level has a positive effect on passive continuance commitment and normative commitment. Monthly salary has a significant positive effect on passive continuance commitment only. Size of company is significantly and negatively correlated with active continuance commitment and positively correlated with passive continuance commitment. Affective commitment has not significant relations with any demographic variables. Finally gender has no significant positive or negative correlation with any of the components of Wang's (2004) organizational commitment model.

Although the results found that not all demographic variables have a significant effect on the components of the organizational commitment model, hypothesis 2 is still supported since most of the important variables, such as work experiences, age and education level positively influences the organizational commitment of employees in Hong Kong's ICT industry. 


\section{Macrothink}

International Journal of Human Resource Studies

ISSN 2162-3058

Table 7 Mean, Standard Deviation and Correlation Matrix between Demographics Variables and Organizational Commitment.

\begin{tabular}{|c|c|c|c|c|c|c|c|c|c|c|c|c|c|c|c|c|}
\hline & Variables & $\mathrm{M}$ & SD & 1 & 2 & 3 & 4 & 5 & 6 & 7 & 8 & 9 & 10 & 11 & 12 & 13 \\
\hline 1 & $\begin{array}{l}\text { Affective } \\
\text { commitment }\end{array}$ & 3.84 & 0.65 & 1.00 & & & & & & & & & & & & \\
\hline 2 & $\begin{array}{l}\text { Active } \\
\text { continuance } \\
\text { commitment }\end{array}$ & 3.83 & 0.70 & $0.64 * *$ & 1.00 & & & & & & & & & & & \\
\hline 3 & $\begin{array}{l}\text { Passive } \\
\text { continuance } \\
\text { commitment }\end{array}$ & 3.41 & 0.85 & 0.06 & $0.15^{* *}$ & 1.00 & & & & & & & & & & \\
\hline 4 & $\begin{array}{l}\text { Normative } \\
\text { commitment }\end{array}$ & 3.56 & 0.67 & $0.31 * *$ & $0.30 * *$ & $0.50 * *$ & 1.00 & & & & & & & & & \\
\hline 5 & $\begin{array}{l}\text { Value } \\
\text { commitment }\end{array}$ & 3.97 & 0.58 & $0.48 * *$ & $0.72 * *$ & $0.19^{* *}$ & $0.34 * *$ & 1.00 & & & & & & & & \\
\hline 6 & $\begin{array}{l}\text { ICT work } \\
\text { experience }\end{array}$ & 2.26 & 0.93 & 0.04 & -0.03 & $0.26 * *$ & $0.12 *$ & -0.02 & 1.00 & & & & & & & \\
\hline 7 & $\begin{array}{l}\text { Number of } \\
\text { years working in } \\
\text { the current company }\end{array}$ & 1.76 & 0.82 & -0.06 & $-0.15^{* *}$ & $0.27 * *$ & $0.11 *$ & -0.03 & $0.63 * *$ & 1.00 & & & & & & \\
\hline 8 & Size of company & 3.50 & 1.27 & -0.04 & $-0.17 * *$ & $0.22 * *$ & 0.03 & $-0.14 * *$ & $0.32 * *$ & $0.29 * *$ & 1.00 & & & & & \\
\hline 9 & Gender & 1.81 & 0.39 & -0.01 & -0.06 & -0.01 & 0.07 & -0.03 & $0.17 * *$ & 0.08 & 0.09 & 1.00 & & & & \\
\hline 10 & Age & 2.76 & 0.93 & 0.01 & -0.01 & $0.26^{* *}$ & $0.16^{* *}$ & 0.04 & $0.72 * *$ & $0.58 * *$ & $0.21 * *$ & $0.11 *$ & 1.00 & & & \\
\hline 11 & Marital Status & 1.44 & 0.51 & -0.07 & $-0.17 * *$ & $0.17^{* *}$ & 0.05 & $-0.13 *$ & $0.65 * *$ & $0.55^{* *}$ & $0.34 * *$ & -0.04 & $0.58 * *$ & 1.00 & & \\
\hline 12 & Education & 3.22 & 0.74 & -0.06 & 0.02 & $0.21^{* *}$ & $0.16^{* *}$ & 0.09 & $0.48 * *$ & $0.33^{* *}$ & $0.28 * *$ & 0.09 & $0.52 * *$ & $0.37 * *$ & 1.00 & \\
\hline 13 & Monthly salary & 3.50 & 1.17 & 0.03 & -0.05 & $0.18^{* *}$ & 0.00 & -0.06 & $0.74 * *$ & $0.58 * *$ & $0.41 * *$ & 0.09 & $0.73 * *$ & $0.61 * *$ & $0.56 * *$ & 1.00 \\
\hline
\end{tabular}

Note: ** Correlation is significant at the 0.01 level (one-tailed test)

* Correlation is significant at the 0.05 level (one-tailed test) 


\subsection{Evaluation of Organization Commitment}

To measure the organizational commitment of employees in Hong Kong's ICT industry, the study applied Wang's (2004) five-component model. The descriptive analysis showed that the highest commitment component is the value commitment with a mean value of 3.97. Affective and active continuance commitments are a little lower with mean values of 3.84 and 3.83, respectively. Passive continuance commitment is the lowest with a mean value of 3.41 and the mean value of normative commitment is the second lowest at 3.56.

\subsubsection{Comparison of Organizational Commitment}

In order to further explore organizational commitment issues, the findings from this research are compared to the results conducted by other researchers in Asian cities. Table 8 shows the comparison between the results of this research and Wang (2004) which obtained when measuring Chinese employees commitment in state-owned and foreign-invested enterprises in China.

Table 8 Comparison of Mean Scores of Components of Organizational Commitment between this Research and Wang's (2004)

\begin{tabular}{lllll}
\hline & This research & $\begin{array}{l}\text { Overall value } \\
\text { (Wang, 2004) }\end{array}$ & $\begin{array}{l}\text { State- } \\
\text { owned } \\
\text { enterprises } \\
\text { (Wang, 2004) }\end{array}$ & $\begin{array}{l}\text { Foreign- } \\
\text { owned } \\
\text { enterprises }\end{array}$ \\
\hline (Wang, 2004)
\end{tabular}

The comparison of the two studies shows that both in Hong Kong and China, value and affective commitments are the most significant components of organizational commitment. However, the importance of other components is different. In this research, active continuance commitment was higher than passive continuance whereas Wang (2004) found the opposite. This difference might be because companies in Hong Kong's ICT industry generally provide on-the-job training and challenging jobs opportunities for their employees whereas China's stated-owned and foreign-invested enterprises studies by Wang place more 
importance on providing job security rather than on-the-job training. The higher mean score of passive continuance commitment from respondents in state-owned enterprises (3.61) as compared to those in foreign-invested enterprises (2.75) supports this argument. State-owned enterprises provide higher stability in business operation and longer employment opportunities for employees. However, foreign-owned enterprises are similar to companies in Hong Kong in that both focus on profits more than employee fringe benefits.

Table 9 shows a comparison of mean scores of individual components between this research and other studies undertaken in China.

Table 9 Comparison of Mean Scores of Components of Organizational Commitment between this Research and Studies in China

\section{Mean Score}

\begin{tabular}{|c|c|c|c|c|}
\hline & $\begin{array}{l}\text { Hong Kong } \\
\text { (This research) }\end{array}$ & $\begin{array}{l}\text { China } \\
\text { (Cheng \& } \\
\text { Stockdale, } \\
\text { 2003)* }\end{array}$ & $\begin{array}{l}\text { China } \\
\text { (Chen \& } \\
\text { Francesco, } \\
2003)^{*}\end{array}$ & $\begin{array}{l}\text { China } \\
\text { (Wang, 2004) }\end{array}$ \\
\hline $\begin{array}{l}\text { Affective } \\
\text { Commitment }\end{array}$ & 3.84 & 3.36 & 3.93 & 3.31 \\
\hline $\begin{array}{l}\text { Active continuance } \\
\text { Commitment }\end{array}$ & 3.83 & - & - & 2.97 \\
\hline $\begin{array}{l}\text { Passive continuance } \\
\text { Commitment }\end{array}$ & 3.41 & - & - & 3.11 \\
\hline $\begin{array}{l}\text { Continuance } \\
\text { Commitment }\end{array}$ & - & 2.65 & 3.21 & - \\
\hline $\begin{array}{l}\text { Normative } \\
\text { Commitment }\end{array}$ & 3.56 & 3.03 & 3.57 & 3.56 \\
\hline
\end{tabular}

* Transformed from a 7-point Likert scale to a 5-point Likert scale

The comparison focuses on the affective, continuance commitment and normative commitment because Cheng \& Stockdale (2003) and Chen \& Francesco (2003) applied the three-component model by Meyer \& Allen (1991) in their studies. The active continuance and passive continuance commitments in this research and Wang's (2004) are compared to the single component of continuance commitment in the other two studies. The comparison shows that organizational commitment in Hong Kong is higher than those in other cities in China.

Table 10 shows a comparison between this research and more recent studies undertaken in other countries.

Table 10 Comparison of Mean Scores of Components of Organizational Commitment 
between this Research and Studies in other Asian cities

\begin{tabular}{|c|c|c|c|c|}
\hline Mean Score & & & & \\
\hline & $\begin{array}{l}\text { Hong Kong } \\
\text { (This research) }\end{array}$ & $\begin{array}{l}\text { Taiwan } \\
\text { (Tsai \& } \\
\text { Huang, 2008) }\end{array}$ & $\begin{array}{l}\text { Lithuanian } \\
\text { (Labatmediene, } \\
\text { Endriulaitiene } \\
\text { \& Gustainiene, } \\
\text { 2007)* }\end{array}$ & $\begin{array}{l}\text { Pakistan } \\
\text { (Tayyab \& } \\
\text { Riaz, 2004) }\end{array}$ \\
\hline $\begin{array}{l}\text { Affective } \\
\text { Commitment }\end{array}$ & 3.84 & 3.26 & 3.01 & 2.90 \\
\hline $\begin{array}{l}\text { Active continuance } \\
\text { Commitment }\end{array}$ & 3.83 & - & - & - \\
\hline $\begin{array}{l}\text { Passive continuance } \\
\text { Commitment }\end{array}$ & 3.41 & - & - & - \\
\hline $\begin{array}{l}\text { Continuance } \\
\text { Commitment }\end{array}$ & - & 2.67 & 2.89 & 2.60 \\
\hline $\begin{array}{l}\text { Normative } \\
\text { Commitment }\end{array}$ & 3.56 & 2.80 & 3.19 & 2.81 \\
\hline
\end{tabular}

* Transformed from a 7-point Likert scale to a 5-point Likert scale

The comparison shows that organizational commitment in Hong Kong is higher than in Lithuanian and Pakistan, and even Taiwan.

\section{Discussion}

The result from testing hypothesis 1 supports Wang's (2004) five-component organizational commitment model for describing the organizational commitment characteristics of employees in Hong Kong's ICT industry. The goodness-of-fit index (GFI) by a confirmatory factor analysis is 0.90 , which although lower than the 0.956 from Wang's study, it is higher than the critical value derived from the other comparable models.

Cheng \& Stockdale (2003) and Chen \& Francesco (2003) found that the three-factor organizational commitment model by Meyer \& Allen (1991) was valid for their studies in the Chinese context. Cheng \& Stockdale (2003) studied employees in foreign-invested companies in China, Cheng \& Francesco (2003) studied companies in South China, and Wang's (2004) respondents were from state-owned and foreign-invested enterprises located in Guangdong, southern China. Their different findings taken derived in a similar context highlight the importance and value of this research in testing the validity of organizational commitment models. The results obtained in this research are similar to those obtained by Wang (2004), which might be due to the fact that employees from Guangdong are geographical close to Hong Kong and therefore might share some similar beliefs and values especially after 1997 with more business interactions and employment opportunities between 


\section{N Macrothink

the two cities.

Recent studies in other countries confirmed that the three-factor model by Meyer \& Allen (1991) had a better fit to employee commitment (Labatmediene et al., 2007; Tayyab, 2007; Wasti, 2005 and Tayyab \& Riaz, 2004). The GFI obtained in conducting confirmatory factor analysis by Labatmediene et al. (2007) for the three-factor model was 0.752 , which was much lower than the critical value 0.9. However, Tayyab (2007) and Tayyab \& Riaz (2004) had 0.90 of GFI in their studies of Pakistan employees and Wasti (2005) had 0.94 from his study in Turkey. All the studies were in areas near to or located in Asia, which to some extent share similar economical, financial or social characteristics. Although their findings supported the validity of Meyer \& Allen's (1991) model, their studies did not take Wang's (2004) model into consideration as this research did. This research confirmed Wang's (2004) model as being suitable for use in Hong Kong's complex cultural and economic environment and showed that it might be better for describing the nature of organizational commitment in other Asian cities.

The Cronbach's alpha values of the construct of the components of the organizational commitment model used in this research are sufficiently high compared to other similar studies. A comparison of Cronbach's alpha values with other relevant research is shown in Table 11. 
Table 11 Comparison of Cronbach's Alpha Value of Organizational Commitment Components

Cronbach's alpha value

\begin{tabular}{|c|c|c|c|c|c|}
\hline & $\begin{array}{l}\text { This } \\
\text { research }\end{array}$ & $\begin{array}{l}\text { Wang } \\
(2004)\end{array}$ & $\begin{array}{l}\text { Tsai \& } \\
\text { Huang } \\
\text { (2008) }\end{array}$ & $\begin{array}{l}\text { Cheng \& } \\
\text { Stockdale } \\
(2003)\end{array}$ & $\begin{array}{l}\text { Chen \& } \\
\text { Francesco } \\
(2003)\end{array}$ \\
\hline $\begin{array}{l}\text { Affective } \\
\text { Commitment }\end{array}$ & 0.815 & 0.71 & 0.789 & 0.78 & 0.91 \\
\hline $\begin{array}{l}\text { Active } \\
\text { Continuance } \\
\text { Commitment }\end{array}$ & 0.854 & 0.79 & - & - & - \\
\hline $\begin{array}{l}\text { Passive } \\
\text { Continuance } \\
\text { Commitment }\end{array}$ & 0.807 & 0.63 & - & - & - \\
\hline $\begin{array}{l}\text { Continuance } \\
\text { Commitment }\end{array}$ & - & 0.73 & 0.700 & 0.52 & 0.86 \\
\hline $\begin{array}{l}\text { Normative } \\
\text { Commitment }\end{array}$ & 0.713 & 0.61 & 0.636 & 0.75 & 0.78 \\
\hline $\begin{array}{l}\text { Value } \\
\text { Commitment }\end{array}$ & 0.794 & 0.81 & - & - & - \\
\hline
\end{tabular}

On average, this research has the highest Cronbach's alpha values compared with the same values derived from studies in China and Taiwan. This suggests that the reliability of the data collected in measuring organizational commitment is comparable to and consistent with other research.

The findings of this research show that affective commitment is a significant component of employee commitment. This result is consistent with previous research both in Asian and Western contexts. It further enhances the existing knowledge of organizational commitment by showing how affective commitment could be promoted. The importance of active continuance and value commitment found in this research also adds more dimensions to organizational commitment that have not been considered either by Meyer \& Allen (1991) or McGee \& Ford (1987). It would be useful for researchers to apply Wang's (2004) model in a Western context and examine its validity. If positive findings are obtained, Wang's five-component model might be a more representative and sophisticated model for explaining organizational commitment in general.

Value commitment is the most significant component for enhancing employees' 
organizational commitment in Hong Kong's ICT industry. This is the employees' feeling that their values and goals match those of their organization and that they are therefore willing to exert maximum effort to contribute to the organization. Senior managers should therefore consult with their employees' needs when formulating organizational strategies and policies and communicate clearly with employees regarding the company's vision and goals. Value commitment will be enhanced if there is high level of transparency relating to the company's development because employees are more likely to have a strong desire to contribute to the success of the company.

The results in testing hypothesis 2 show that some demographic variables have positive effects on organizational commitment. Work experiences in the ICT industry and the number of years working in the same company are related to passive continuance commitment and normative commitment. By encouraging employees to work in their company for a longer time with explicit support in personal and career development, and by providing long-term benefits, employees would feel more of a moral obligation to stay with the same company for their entire career. Employees would fear losing benefits and opportunities to learn if they leave and their passive continuance and normative commitment will gradually increase.

The findings of this research show that age has a positive effect on passive continuance and normative commitment. As employees grow older they become more familiar with the company's operations and possess more market knowledge. Retention of such employees avoids loss of corporate knowledge and assets, and increases organizational competitiveness. Education level also has a positive effect on passive continuance commitment and normative commitment. Managers should encourage and support employees to have continuous studies to enhance their education level. Mature employees with a high education level would be pleased to work in the organizations if they feel that they are receiving appropriate support from senior managers. They would have a greater sense of moral obligation to continuously contribute to the best of their ability and would have a high level of passive continuance and normative commitment.

The comparison with Wang's results in China shows that except for value commitment, the mean scores of the other four components in this research are higher than the results obtained by Wang (2004). This suggests that the average employees' commitment to organizations in Hong Kong is higher than in China. Since Wang's study was of employees in China, no matter the employees worked in state-owned or foreign-invested enterprises, the commitment to their organization was based more on the continuous operation of the company. It is likely that such employees might lose their job if their company ceased its business in China, so the value commitment is higher because of higher internalization and congruence of values and goals. It might be the same situation in Hong Kong. The burst of the dot-com bubble in 2000 and subsequent of the ICT industry caused a chain reaction: many IT companies discontinued their business and the demand for IT professionals declined drastically. During that time, IT professionals were more willing to commit to their employer with corporate survival as their major goal. This explains the high level of value commitment found in this research.

Normative commitment is at a low level both in this research and in Wang's (2004). Since 
some of the employees in Wang's study worked in foreign-invested enterprises, which are similar to companies in Hong Kong in as much as they operate in a highly competitive environment, their employees might have higher turnover intention and lower obligation to stay with the same company if the industry is more dynamic and the demand for manpower is high.

The findings in this research are consistent with other studies in China by Cheng \& Stockdale (2003) and Chen \& Francesco (2003) that applied the three-component model by Meyer \& Allen (1991). The comparison of results found that affective commitment is not more significant than the other two components. This suggests that although Hong Kong was once ruled by Britain and is an international city with an advanced financial and economic infrastructure, employees in Hong Kong still work in a predominately Chinese culture and share similar commitment characteristics with employees in China.

In the comparison of organizational commitment with the studies in Taiwan, Lithuania and Pakistan, although the difference might be due to different targets groups and collectivism in Chinese culture might be the critical factors that positively influence employees' in group and organizational citizen behavior (Voelpel \& Han, 2005; Hutchings \& Michailova, 2006) and induce a higher level of employee commitment than was found in this research. The lower level of commitment in Taiwan could be explained by its limited economic and political interaction with the West, which led to an economic recession in the last eight years. This is different to China which has had more interaction with the West since economic deregulation (Chen, Wu and Chung, 2008). It appears as though employees in Taiwan will have a lower level of commitment to their company if they are uncertain about their economic future.

\section{Limitations and Future Research}

This research studied the organizational commitment amongst employees in Hong Kong's ICT industry only, further studies are recommended to consider other industries in Hong Kong. In addition, more attributes could be studied, such as personal characteristics, job characteristics, organizational support, and job satisfaction in order to enhance the value of the evaluation of employees' behaviour in commitment to their organizations. Studying only Hong Kong's industry might limit the generalization of the results to employees in other cities that near to Hong Kong. Since it would appear that very few studies applied Wang's (2004) organizational commitment model, further research is recommended on other cities in order to provide better generalization of results to the Chinese context. In addition, the validity of Wang's model in this research might imply that her model would also be appropriate for use in a Western context because China-based enterprises have investments in western countries which might be affected by the Chinese working behaviour. Research could be done by applying Wang's model in a western context in order to determine whether or not her model could be universally applied. 
References

Angle, H. L. and Perry, J. L. (1981). An empirical assessment of organizational commitment and organizational effectiveness. Administrative Science Quarterly, 26(1), 1-14.

Bashir, S. and Ismail Ramay, M. (2008). Determinants of organizational commitment: a study of information technology professionals in Pakistan. Journal of Behavioral and Applied Management, 9(2), 226-238.

Becker, H. S. (1960). Notes on the concept of commitment. American Journal of Sociology, $66(1), 32-40$.

Brooks, G. (2002). Knowledge-based structures and organizational commitment. Management Decision, 40(5/6), 566-573. http://dx.doi.org/10.1108/00251740210433954.

Chen, Y. H., Wu, J. J. and Chung, Y. S. (2008). Cultural impact on trust: a comparison of virtual communities in China, Hong Kong, and Taiwan. Journal of Global Information Technology Management, 11(1), 28-48.

Chen, Z.X. and Francesco, A.M. (2003). The Relationship between the three components of commitment and employee performance in China. Journal of Vocational Behavior, 62(3), 490-510. http://dx.doi.org/10.1016/S0001-8791(02)00064-7.

Cheng, Y. and Stockdale, M.S. (2003). The validity of the three-component model of organizational commitment in a Chinese context. Journal of Vocational Behavior, 62(3), 465-489. http://dx.doi.org/10.1016/S0001-8791(02)00063-5.

Hackett, R. D., Bycio, P. and Hausdorf, P. A. (1994). Further assessments of Meyer and Allen's (1991) three-component model of organizational commitment. Journal of Applied Psychology, 79(1), 15-23. http://dx.doi.org/10.1037/0021-9010.79.1.15.

Hofstede, G. (1993). Cultural constraints in management theories. The Academy of Management Executive, 7(1), 81-94. http://dx.doi.org/10.5465/AME.1993.9409142061.

Hutchings, K. and Michailova, S. (2006). The impact of group membership on knowledge sharing in Russia and China. International Journal of Emerging Markets, 1(1), 21-34. http://dx.doi.org/10.1108/17468800610644988

Jaros, S. J. (1997). An assessment of Meyer and Allen's (1991) three-component model of organizational commitment and turnover intentions. Journal of Vocational Behavior, 51(3), 319-337. http://dx.doi.org/10.1006/jvbe.1995.1553.

Kelman, H. C. (1958). Compliance, identification, and internalization three processes of attitude change. The Journal of Conflict Resolution, 2(1), 51-60.

Labatmediene, L., Endriulaitiene, A. and Gustainiene, L. (2007). Individual correlates of organizational commitment and intention to leave the organization. Baltic Journal of Management, 2(2), 196-212. http://dx.doi.org/10.1108/17465260710750991.

Lin, C. P. (2007). To share or not to share: modeling tacit knowledge sharing, its mediators and antecedents. Journal of Business Ethics, 70(4), 411-428. http://dx.doi.org/10.1007/s10551-006-9119-0.

Ling, W, Zhang, Z. and Fang, L. (2001). A study of the organizational commitment of Chinese employees. Social Science in China, 128(2), 90-102.

Mathieu, J. E. and Zajac, D. M. (1990). A review and meta-analysis of the antecedents, correlates, and consequences of organizational commitment. Psychological Bulletin, 108(2), 171-194. http://dx.doi.org/10.1037/0033-2909.108.2.171.

Mayer, R. C. and Schoorman, F. D. (1992). Predicting participation and production outcomes through a two-dimensional model of organizational commitment. Academy of Management Journal, 35(3), 671-684. http://dx.doi.org/10.2307/256492.

McGee, G. W. and Ford, R. C. (1987). Two (or more?) dimensions of organizational 
commitment: reexamination of the affective and continuance commitment scales. $\begin{array}{llll}\text { Journal of Applied } & \text { Psychology, }\end{array}$ http://dx.doi.org/10.1037/0021-9010.72.4.638.

Mclver, J. P. and Carmines, E. G. (1981). Unidimensional scaling, Beverly Hill, CA: Sage Publication.

Meyer, J. P. and Allen, N. J. (1991). A three-component conceptualization of organizational commitment. Human Resource Management Review, 1(1), 61-89. http://dx.doi.org/10.1016/1053-4822(91)90011-Z.

Meyer, J.P., \& Allen, N. J. (1997). Commitment in the workplace: theory, research, and application, Newbury Park, CA: Sage Publication.

Meyer, J. P., Allen, N. J. and Smith, C. A. (1993). Commitment to organizations and occupations: extension and test of a three-component conceptualization. Journal of Applied Psychology, 78(4), 538-551. http://dx.doi.org/10.1037/0021-9010.78.4.538.

Mowday, R. T., Steers, R. M. and Porter, L. W. (1979). The measurement of organizational commitment. Journal of Vocational Behavior, 14(2), 224-247. http://dx.doi.org/10.1016/0001-8791(79)90072-1.

O'Reilly, C. and Chatman, J. (1986). Organizational commitment and psychological attachment: the effects of compliance, identification, and internalization on prosocial behaviour. Journal of Applied Psychology, 71(3), 492-499. http://dx.doi.org/10.1037/0021-9010.71.3.492.

Porter, L. W., Steers, R. M., Mowday, R. T. and Boulian, P. V. (1974). Organizational commitment, job satisfaction, and turnover among psychiatric technicians. Journal of Applied Psychology, 59(5), 603-609. http://dx.doi.org/10.1037/h0037335

Tayyab, S. (2007). An empirical assessment of organizational commitment measures. Pakistan Journal of Psychological Research, 22(1/2), 1-21.

Tayyab, S. and Riaz, M. N. (2004). Validation of the three-component model of organizational commitment in Pakistan. Pakistan Journal of Psychological Research, 19(3/4), 123-149.

Tsai, M. T. and Huang, C. C. (2008). The relationship among ethical climate types, facets of job satisfaction, and the three components of organizational commitment: a study of nurses in Taiwan. Journal of Business Ethics, 80(3), 565-581. http://dx.doi.org/10.1007/s10551-007-9455-8

Voelpel, S. C. and Han, Z. (2005). Managing knowledge sharing in China: the case of Siemens ShareNet. Journal of Knowledge Management, 9(3), 51-63. http://dx.doi.org/10.1108/13673270510602764.

Wang, Y. (2004). Observations on the organizational commitment of Chinese employees: comparative studies of state-owned enterprises and foreign-invested enterprises. International Journal of Human Resource Management, 15(4), 649-669. http://dx.doi.org/10.1080/0958519042000192889.

Wasti, S. A. (2005). Commitment profiles: combinations of organizational commitment forms and job outcomes. Journal of Vocational Behavior, 67(2), 290-308. http://dx.doi.org/10.1016/j.jvb.2004.07.002.

Wong, Y. T., Ngo, H. Y. and Wong, C. S. (2002). Affective organizational commitment of workers in Chinese joint ventures. Journal of Managerial Psychology, 17(7), 580-598. http://dx.doi.org/10.1108/02683940210444049. 
Appendix

Appendix 1. Questionnaire for Organizational Commitment (Wang, 2004)

Affective Commitment

AC1: I am extremely glad that I chose this company to work for over others I was considering at the time I joined.

AC2: $\quad$ I talk up this company to my friends as a great company to work for.

AC3: $\quad$ I am proud to tell others that I am part of this company.

Active Continuance Commitment

ACC1: I work for the company because it provides me with many on-the-job training opportunities.

ACC2: $\quad$ I work for the company because it is a good chance to realize my goals.

ACC3: I work for the company because I can make full use of what I have learned here.

ACC4: I work for the company because of the challenging job.

ACC5: I work for the company because there are many opportunities for promotion.

Passive Continuance Commitment

PCC1: I work for the company because I cannot find a better one.

PCC2: I cannot quit the job arbitrarily because I have to support my family.

PCC3: $\quad$ I work for the company because I do not want to lose my fringe benefits.

Normative Commitment

NC1: $\quad$ I consider it my obligation to work for the same company all the while.

NC2: $\quad$ I would like lifetime employment if possible.

NC3: I would do any job as long as I work here.

Value Commitment

VC1: $\quad$ I am willing to put in a great deal of effort beyond that normally expected in order to help this company to be successful.

VC2: $\quad$ I really care about the fate of this company.

VC3: $\quad$ This company really inspires me to do my job to the very best of my abilities

VC4: $\quad$ One should work with utmost efforts for the company. 